\title{
PENERAPAN MODEL PROBLEM BASED LEARNING BERBANTUAN INFORMATION TECHNOLOGY UNTUK MENINGKATKAN HASIL BELAJAR PESERTA DIDIK PADA MATERI FLUIDA STATIS
}

\author{
Sulaiman$^{1}$, Abdul Gani Haji², Muhammad Syukri ${ }^{3}$ \\ ${ }^{1}$ Program Studi Pendidikan IPA Program Pascasarjana Universitas Syiah Kuala Banda Aceh \\ ${ }^{2}$ Program Studi Pendidikan Kimia FKIP Universitas Syiah Kuala Banda Aceh \\ ${ }^{3}$ Program Studi Pendidikan Fisika FKIP Universitas Syiah Kuala Banda Aceh \\ E-mail: sloimansaleh@gmail.com
}

\section{DOI : 10.26418/jpmipa.v9i2.25830}

\begin{abstract}
As one of the schools implementing the 2013 curriculum, Sekolah Menengah Atas Negeri (SMAN) 1 Sigli is required to use IT in improving learners' learning outcomes. This is an obstacle in the implementation of the 2013 curriculum in SMAN 1 Sigli, it is necessary to apply IT in the learning. This study aims to determine the effect of IT assisted PBL model on student learning outcomes on static fluid material at SMAN 1 Sigli. Quasi experimental method with pretest posttest, control group design. Selection of sample by random sampling technique, choose 2 (two) from 5 (five) class. The data was collected using test questions to see the effect of IT assisted PBL model on students' learning outcomes on static fluid materials. The result of the research shows that the students' learning achievement reaches $85 \%$ high category in the experimental class and the control class is only 65\%, the result of hypothesis testing is tcount> ttable is 2.61> 1.68. IT-assisted PBL models can be applied in learning to make learners more active, but there are weaknesses in problem-forming and hypothesizing activities.
\end{abstract}

Keywords: IT assisted PBL; fluida; learning outcomes.

Kurikulum 2013 merupakan kurikulum yang diterapkan sejak tahun 2013 untuk jenjang sekolah dasar (SD) hingga SMA. Kurikulum ini menuntut guru dan peserta didik cakap dalam menggunakan IT (Muhson, 2010). Supaya informasi yang didapatkan bukan hanya dari buku atau guru saja tetapi bisa juga dari web, hal ini tentu saja sangat menguntungkan peserta didik, dan disisi lain juga dapat menghasilkan guru dan peserta didik yang lebih kreatif dan berwawasan luas. Oleh karena itu, untuk mewujudkan peserta didik yang kreatif dan berwawasan luas, terutama dalam bidang keilmuan maka perlu diperbaiki metode pembelajaran dan pentingnya penggunaan IT, terutama dalam pembelajaran fisika, karena pada hakikatnya pengetahuan tersebut berdasarkan fakta.

Belajar mengajar merupakan proses dimana seorang guru dituntut untuk lebih kreatif dalam menggunakan metode pembelajaran sehingga peserta didik dapat memahami apa yang dijelaskan oleh guru. Guru bukan 
menjadi fokus dalam proses belajar mengajar, tetapi peserta didik sangat dituntut untuk lebih kritis dalam mengembangkan ide-ide atau informasi yang didapatkan dari berbagai sumber, untuk mendapatkan informasi guru dan peserta didik diharapkan mampu menggunaan IT. Penggunaan IT dalam pembelajaran merupakan salah bentuk usaha untuk meningkatkan hasil belajar.

Saat ini, hasil pemikiran dan produk dari penelitian yang dilakukan para ahli perlu pengembangan dan penerapan IT dalam pembelajaran fisika. Hasil pengembangannya diarahkan pada produk ilmiah, metode ilmiah dan sikap ilmiah yang dimiliki peserta didik, sehingga diharapkan dapat meningkatkan hasil belajarnya. Namun penerapan kurikulum 2013 pada mata pelajaran fisika belum sesuai dengan yang diharapkan oleh pemerintah. Hal ini, banyak kendala di lapangan yang menghambat proses penerapan tersebut.

Penerapan kurikulum 2013 dalam pembelajaran dituntut untuk menggunakan pendekatan saintifik yang merupakan pendekatan ilmiah. Hal ini sesuai dengan Kemendikbud (2013:1), bahwa pendekatan saintifik dimaksudkan untuk memberikan pemahaman kepada peserta didik dalam mengenal, memahami berbagai materi menggunakan pendekatan ilmiah, bahwa informasi bisa berasal dari mana saja, kapan saja, tidak bergantung pada informasi searah dari guru. Salah satu pembelajaran yang cocok dengan pendekatan ilmiah (saintifik) adalah pembelajaran bebasis masalah atau sering disebut dengan problem based learning (PBL) berbantuan IT.
Berdasarkan hasil studi kasus di SMA 1 Sigli salah satu yang menghambat proses penerapan kurikulum 2013 adalah implementasi di sekolah belum sesuai dengan yang diharapkan, karena pemahaman guru masih beragam. Hal ini menyebabkan sebagian guru belum maksimal menerapkan kurikulum 2013, padahal sebagian mereka sudah pernah mengikuti pelatihan, namun penguasaan IT masih terbatas. Guru SMA Negeri 1 Sigli baru mengerti kurikulum 2013 hanya tentang evaluasi dan bentuk nilai, kategori nilai juga masih sulit dinilai oleh guru misalnya pada penilaian psikomotor dan sikap. Oleh karenanya, kebanyakan guru dalam menjelaskan pelajaran masih menggunakan kurikulum KTSP, tidak menggunakan model atau metode pembelajaran yang bervariasi dan saintifik.

Model PBL merupakan suatu pendekatan pembelajaran dimana peserta didik mengerjakan permasalahan yang autentik dengan maksud untuk menyusun pengetahuan mereka sendiri, mengembangkan inkuiri dan keterampilan berpikir tingkat lebih tinggi, mengembangkan kemandirian dan percaya diri. Pemilihan model pembelajaran perlu dilakukan untuk menarik minat belajar peserta didik, karena variasi model atau metode yang digunakan oleh guru bisa mengakibatkan penyajian bahan pelajaran lebih menarik perhatian peserta didik, mudah diterima peserta didik dan kalas menjadi hidup (Trianto, 2010).

Beberapa hasil penelitian telah membuktikan keefektifan penerapan model PBL dalam pembelajaran diantaranya Bekti dan Herman (2013) mengatakan model PBL dapat 
mempengaruhi hasil belajar peserta didik. Model PBL dapat mempengaruhi minat dan pemahaman peserta didik (Muhson, 2009); model PBL dapat meningkatkan kemampuan berpikir kritis peserta didik (Sulaiman, 2013; Paramitha, dkk., 2014; Zabit, 2010); kritis dan kreatif (Eldy dan Sulaiman, 2013); serta hubungan antara keyakinan peserta didik dengan pemahaman konsep (Sahin, 2010). Penerapan autentik PBL dapat meningkatkan kemampuan berpikir siswa (Hudha, dkk., 2017). Pembelajaran model PBL sangat efektf diterapkan dalam pembelajaran (Mukhtar, 2013; Kurniawati dan Dhamas, 2013), dan juga dalam pengembangan bahan ajar (Juniati dkk., 2015; Muchsin dkk., 2015), meningkatkan ketuntasan belajar siswa (Atmojo, 2013). Model PBL dapat dibuktikan keefektifannya, misalnya pada pengembangan modul (Fidiana dkk., 2012; Festiana dkk., 2014), pengembangan perangkat pembelajaran (Fakhrudin dkk., 2013). Di samping itu, penerapan IT dalam pembelajaran merupakan suatu tuntutan (Muhson, 2010) yang harus digunakan dalam mencari informasi sehingga mampu mempengaruhi hasil belajar peserta didik (Wahyudin dkk., 2010) dan bagi guru kegunaan IT juga dapat membantu kinerja guru dalam melaksanakan pembelajaran (Caroline dan Bernard, 2011; Fabienne dkk., 2012; dan Samuel dkk., 2013), penilaian hasil belajar peserta didik (Chen dkk., 2014; dan Nikou dan Anastasios, 2015). Berdasarkan hasil penelusuran yang dilakukan, belum ada penelitian yang menggunakan model pembelajaran PBL berbantuan IT, terutama untuk meningkatkan hasil belajar materi fluida statis.
Penerapan kurikulum 2013 selama ini belum efektif, fasilitas pendukung masih kurang dan kemampuan IT masih terbatas. Oleh karena itu perlu pembelajaran yang tepat dan penggunaan media pembelajaran berupa IT. Dengan demikian pada penelitian ini dikaji tentang pengaruh model PBL berbantuan IT dalam pembelajaran fluida statis terhadap hasil belajar peserta didik. Guru lebih kreatif dalam mengelola pembelajaran dan peserta didik diharapkan mampu mengembangkan ide-ide mereka dengan kreatif, kritis serta berinovasi dan mampu menyelesaikan permasalahan-permasalahan yang diberikan oleh guru.

\section{METODE}

Penelitian ini menggunakan metode penelitian quasi experimental. Desain penelitian berbentuk pretest posttest, control group design. Penelitian ini menggunakan 2 (dua) kelas, sebelum pembelajaran peserta didik diberikan tes untuk melihat kemampuan awal, kemudian memberikan pembelajaran dengan perlakuan model PBL berbantuan IT pada kelas eksperimen dan model PBL tanpa bantuan IT di kelas kontrol sebagai kelas pembanding. Pemilihan sampel dilakukan dengan menggunakan teknik random sampling, yaitu dengan memilih 2 (dua) kelas sampel dari 5 (lima) kelas yang terdapat di SMAN 1 Sigli dengan masing-masing kelas mempunyai 30 siswa. Pengumpulan data dilakukan dengan memberikan soal tes untuk melihat pengaruh model PBL berbantuan IT terhadap hasil belajar peserta didik pada materi fluida statis 
Penelitian ini dilaksanakan pada SMAN 1 Sigli semester genap tahun ajaran 2016/2017 selama 2 bulan, yaitu pada bulan Maret - April 2017. Berdasarkan hasil observasi awal yang peneliti lakukan pada SMAN 1 Sigli dan berpedoman pada silabus bahwa materi fluida statis berlangsung pada bulan April 2017, dengan rincian 12 Jam Pelajaran dalam empat pertemuan. Instrumen tes hasil belajar yang digunakan dalam penelitian ini adalah instumen tes berupa soal-soal mengenai hasil belajar pada materi fluida. Instrumen berupa tes dalam bentuk pilihan ganda yang mencakupi ranah kognitif Taxsonomi Bloom dengan jumlah jumlah soal 16 buah. Pengumpulan data dilakukan sebelum dan sesudah pembelajaan. Teknik analisis data tes dilakukan dengan penghitungan $\mathrm{N}$-Gain yang diperoleh dan dinormalisasi oleh selisih antara skor maksimal dengan skor tes awal (Hake, 1999). Nilai Gain yang diperoleh digunakan untuk melihat peningkatan hasil belajar peserta didik sebelum dan sesudah belajar dengan model PBL berbantuan IT. Klasifikasi nilai $N$-Gain, kategori tinggi jika $N$ Gain > 0,70; kategori sedang jika 0,30 $\leq N$-Gain $\leq 0,70$; dan kategori rendah jika $N$-Gain $<0,30$.

\section{HASIL DAN PEMBAHASAN}

Uji normalitas dalam penelitian ini menggunakan uji Lilliefors dengan kriteria pengujian pada tingkat kesalahan 0,05 , dengan tujuan untuk mengetahui distribusi skor data hasil belajar peserta didik kedua kelas. Berdasarkan hasil uji normalitas menunjukkan bahwa skor pretest, postttest, dan $N$-Gain untuk hasil belajar peserta didik kelas eksperimen dan kelas kontrol diperoleh Nilai $\mathrm{L}_{\text {hitung }}$

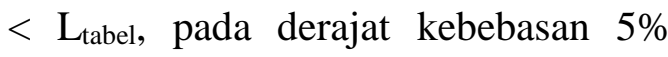
dengan kesimpulan bahwa data kedua kelas terdistribusi normal. Uji homogenitas dalam penelitian ini menggunakan uji F. Hasil analisis data menunjukkan bahwa uji homogenitas skor pretest homogen karena $\mathrm{F}_{\text {hitung }}<$ $F_{\text {tabel}}$. Apabila harga $F_{\text {hitung }}$ lebih kecil dari $F_{\text {tabel, }}$ maka dapat dinyatakan bahwa varian kedua kelas memiliki kemampuan yang sama (homogen). Hal ini menunjukkan bahwa kedua kelas sampel memiliki kemampuan yang sama dan merupakan syarat untuk penelitian eksperimen.

Data pretest hasil belajar peserta didik berdistribusi normal dan homogen, maka pengujian hipotesis tentang hasil belajar dilakukan dengan uji t. Pengujian ini dimaksudkan untuk melihat perbedaan dua rata-rata skor peningkatan hasil belajar peserta didik antara kelas eksperimen dan kelas kontrol. Berdasarkan hasil pengujian rata-rata data pretest dan posttest yaitu

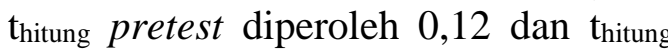
posttest diperoleh 2,61. Hasil pengujian thitung untuk pretest lebih besar dari pada $t_{\text {tebel, }}$ maka kesimpulnya tidak terdapat perbedaan signifikan antara kedua kelas tersebut. Pada posttest terdapat perbedaan, artinya kedua kelas tersebut tidak memiliki kemampuan yang sama, atau terdapat perbedaan kemampuan. Hal ini dipengaruhi oleh model pembelajaran yaitu PBL berbantuan IT pada kelas eksperimen. Pembelajaran dengan model PBL berbantuan IT dapat meningkatkan hasil belajar peserta didik dibandingkan dengan model PBL tanpa adanya IT.

Data skor rata-rata $\mathrm{N}$-Gain untuk hasil belajar terdistribusi normal dan homogen. Pengujian perbedaan dua rata-rata dan pengujian hipotesis dilakukan dengan uji t. Berdasarkan 
data hasil uji statistik terhadap $N$-Gain kedua kelas diperoleh bahwa $t_{\text {hitung }}>$ $t_{\text {tabel }}$ yaitu 2,51>1,68, maka dapat disimpulkan bahwa terdapat perbedaan antara kelas eksperimen dengan kontrol. Nilai skor di tiap-tiap ranah kognitif pada kelas eksperimen lebih tinggi dibandingkan kelas kontrol. Hal ini menunjukkan adanya pengaruh pembelajaran dengan model PBL berbantuan IT terhadap hasil belajar peserta didik. Peningkatan hasil belajar peserta didik kelas eksperimen dan kontrol ditinjau dari nilai pretestpostest secara rinci dapat dilihat dari selisih skor pretest dengan skor postest yang diperoleh peserta didik sebelum dan sesudah pembelajaran dengan model PBL berbantuan IT. Persentase $N$-Gain hasil belajar peserta didik diklasifikasi dalam tiga kategori, yaitu rendah, sedang dan tinggi.

Tabel 1. Persentase $n$-gain hasil belajar peserta didik kelas eksperimen dan kontrol

\begin{tabular}{ccc}
\hline \multirow{2}{*}{ Kategori $\boldsymbol{N}$-Gain } & \multicolumn{2}{c}{ Persentase } \\
\cline { 2 - 3 } & Kelas Eksperimen & Kelas Kontrol \\
\hline Rendah & 0 & 0 \\
\hline Sedang & 15 & 40 \\
\hline Tinggi & 85 & 60 \\
\hline
\end{tabular}

Berdasarkan Tabel 1 terlihat bahwa kelas eksperimen mencapai 85\% peningkatan hasil belajar peserta didik pada kategori "tinggi", dibandingkan kelas kontrol $60 \%$ pada kategori "tinggi". Hal ini menunjukkan bahwa hasil belajar peserta didik dipengaruhi oleh model yang tepat, penggunaan IT dalam pembelajaran menyebabkan peserta didik tekun dan antusias dalam belajar. Melalui IT peserta didik menjadi leluasa dalam menggali informasi yang dibutuhkan. Hal ini sesuai dengan penelitian Samuel (2013) bahwa penerapan IT dalam pembelajaran secara menyeluruh dapat membantu peserta didik dalam memecahkan masalah. Pemecahan masalah yang dimaksud merupakan kemampuan peserta didik dalam memahami konsep dan menggali informasi secara luas. Melalui IT juga memudahkan pelaksanaan dan penerapan kurikulum 2013 dalam pembelajaran.

Perpaduan model PBL dengan IT yang diterapkan dalam pembelajaran, khususnya dalam pembelajaran fisika membuat peserta didik mudah memahami konsep yang selama ini dianggap sulit. Memahami konsep fisika melalui fenomena yang ditampilkan oleh guru berupa animasianimasi, kemudian peserta didik menemukan contoh dalam kehidupan sehari-hari. Peserta didik dengan semangat berhipotesis terhadap pertanyaan permasalahan yang diajukan guru, dan menemukan jawaban dengan mudah setelah tampilan animasi serta memberi solusi yang tepat terhadap permasalahan tersebut. Hal inilah yang diharapkan melalui penerapan IT dalam pembelajaran.

Meningkatnya hasil belajar peserta didik dilihat dari pencapaian ranah kognitif pada materi fluida statis. Hal ini disebabkan adanya ketertarikan dan minat peserta didik dalam mengikuti pembelajaran dengan model PBL berbantuan IT (Wahyudin, 2010). Pembelajaran dengan dilengkapi bahan ajar berupa animasi dapat memudahkan 
peserta didik dalam menguasai konsepkonsep yang disajikan oleh guru. Hasil pengujian hipotesis menunjukkan bahwa penerapan pembelajaran dengan model PBL berbantuan IT lebih efektif dalam meningkatkan hasil belajar peserta didik dibanding penerapan pembelajaran dengan model PBL tanpa bantuan IT. Hasil tersebut didukung oleh pendapat Sulaiman (2013), bahwa selain hasil belajar, model PBL juga efektif terhadap berpikir kritis dan kreatif peserta didik. Pembelajaran dengan model PBL berbantuan IT yang diterapkan pada kelas eksperimen melibatkan peserta didik dapat melatih kemampuannya dalam menguasai konsep yang telah diajari dan mampu menyelesaikan masalah-masalah yang dihadapi.

Peningkatan hasil belajar tertinggi kelas eksperimen pada ranah analisis (C4). Sesuai dengan pembelajaran yang dilakukan yakni melalui pembelajaran model PBL berbantuan IT, dimana peserta didik diberi kesempatan untuk menemukan pengetahuan sebanyak mungkin baik dalam melakukan percobaan ataupun dengan pengalama-pengalaman yang ditemukan dalam kehidupan sehari-hari sehingga hal ini membuat kemampuan analisis peserta didik meningkat lebih tinggi dibandingkan kemampuan lainnya.

Peningkatan hasil belajar tertinggi kelas kontrol adalah pada ranah pengetahuan (C1). Hal ini disebabkan karena peserta didik mampu mengingat konsep-konsep yang dijelaskan oleh guru. Peningkatan ranah kognitif untuk kategori rendah kelas eksperimen pada ranah pemahaman (C2). Ranah pemahaman lebih rendah dari ranah analisis, sedangkan kelas kontrol kategori terendah adalah pada ranah aplikasi, hal ini disebabkan karena peserta didik belajar dengan model PBL tanda adanya IT sehingga mereka belum mampu mengaplikasikan berbagai konsep fisika dalam kehidupan seharihari.

\section{SIMPULAN DAN SARAN}

Berdasarkan hasil penelitian dan pembahasan dapat disimpulkan bahwa penerapan model PBL berbantuan IT dalam pembelajaran materi fluida statis dapat meningkatkan hasil belajar peserta didik di SMAN 1 Sigli. Hal ini terlihat dari hasil pengujian hipotesis didapat bahwa $t_{\text {hitung }}>t_{\text {tabel }}$ yaitu: 2,61 $>$ 1,68, di mana hipotesis alternatif diterima.

Penulis mengucapkan terimakasih kepada Bapak Prof. Dr. Yusrizal, M.Pd., Samsul Bahri, M.Pd., Ibu Dra. Nurulwati, M.Pd., Dra. Elisa Kasli, M.Pd., dan Sari Rizki, M.Psi sebagai validator instrumen penelitian. Ibu Habibah, S.Pd dan Asmiah, S.Pd sebagai pengamat pelaksanaan PBM. Peserta didik SMAN 1 Sigli, serta kepada seluruh pihak yang turut membantu dalam pelaksanaan penelitian.

\section{DAFTAR PUSTAKA}

Atmojo, S.E. 2013. Implementasi Model Problem Based Learning di Sekolah. Jurnal Pendidikan Matematika dan IPA. 4(1):35-46.

Bekti, W., dan Herman, D.S. 2013. Pengaruh Problem-Based Learning Terhadap Hasil Belajar Ditinjau dari Motivasi Belajar PLC di SMK. Jurnal Pendidikan Vokasi. 3(2):178-191.

Caroline, T., dan Bernard, V. 2011. Attention Paid to Feedback 
Provided by a Computer-Based Assessment for Learning on Information Literacy. Journal Computers and Education. (56):923-930.

Chen, H.C., Hsiao, C.S., Ming, H.C., Jiun, Y.W., Jie, L.T., dan Tzyy, P.J. 2014. Eye Movements Predict Students' ComputerBased Assessment Performance Of Physics Concepts In Different Presentation Modalities. Journal Computers and Education. (74):61-72.

Eldy, E.F. dan Sulaiman, F. 2013. Integrated PBL Approach: Preliminary Findings towards Physics Students' Critical Thinking and Creative-Critical Thinking. International Journal of Humanities and Social Science. (2):18-25.

Fabienne, M., Theo, J.H.M., Caroline, T., dan Bernard, V. 2012. Effects of Feedback in a ComputerBased Assessment for Learning. Journal Computers and Education. (58):263-272.

Fahkrudin, A., Hartono dan Sutikno. 2013. Pengembangan Perangkat Pembelajaran Fisika Kesehatan Berbasis Masalah untuk Meningkatkan Penalaran dan Penguasaan Konsep Mahapeserta didik Kebidanan. Jurnal Pendidikan Fisika Indonesia. (9):106-112.

Festiana, I., Sarwanto dan Sukarmin. 2014. Pengembangan Modul Fisika Berbasis Masalah pada Materi Listrik Dinamis untuk Meningkatkan Kemampuan Berpikir Kreatif Peserta didik
SMA. Jurnal Inkuiri. 3 (II) 3647. Tersedia di: http://jurnal.fkip.uns.ac.id/index. php/sains. Diakses: 22 Agustus 2016.

Fidiana, L., Bambang, S., dan Pratiwi, D. 2012. Pembuatan dan Implementasi Berbasis Masalah untuk Meningkatkan Kemandirian Belajar Peserta didik Kelas XI. Unnes Physics Education Journal. 1 (1). 2012. Tersedia di: http://journal.unnes.ac.id/sju/inde x.php/upej. Diakses: 22 Agustus 2016.

Hake, R.R. 1999. Interactive Engagement Versus Traditional Methods: A Six-Thousand Student Survey of Mechanics Test Data For Introductory Physics Courses. American Journal of Physics. 66(1):23-46.

Hudha, M.N., Aji, S.D., Permatasari, A., dan Purnama, R.D. 2017. Autentik Problem Based Learning untuk Meningkatkan Kemampuan Berpikir Siswa. Jurnal Pendidikan Matematika dan IPA. 8(1):64-70.

Juniati I., Zulkardi, dan Somakim. 2015. Pengembangan Bahan Ajar Materi Aturan Pencacahan Menggunakan Pembelajaran Berbasis Masalah di SMA. Jurnal Didaktik Matematika. 2(2):2355-4185.

Kemendikbud. 2013. Pendekatan dan Strategi Pembelajaran. Jakarta: Kementerian Pendidikan dan Kebudyaan. 
Kurniawati, I.L., dan Dhamas, M.A. 2013, Pengembangan Bahan Ajar Berbasis Masalah Pada Mata Pelajaran Kimia SMA Kelas X dalam Materi Hidrokarbon. Seminar Nasional FMIPA UNDIKSHA III.

Muchsin, Sutikno, dan Masturi. 2015. Bahan Ajar Fisika dengan Pendekatan Problem Based Learning. Prosiding Seminar Nasional Fisika (E-Journal) SNF. (IV) 2339-0654. Tersedia: http://snf-unj.ac.id/kumpulanprosiding/snf2015/. Diakses: 22 Agustus 2016

Muhson, A. 2009. Peningkatan Minat Belajar dan Pemahaman Mahapeserta didik Melalui Penerapan Problem-Based Learning. Jurnal Kependidikan. 39(2):171-182.

Muhson, A. 2010. Pengembangan Media Pembelajaran Berbasis Teknologi Informasi. Jurnal Pendidikan Akuntansi Indonesia. 8(2):1-10

Mukhtar. 2013. Pengembangan Bahan Ajar Matematika Berbasis Masalah untuk Memfasilitasi Pencapaian Kemampuan Penalaran dan Pemahaman Konsep Peserta didik. Prosiding Semirata FMIPA Universitas Lampung.

Nikou, S.A., dan Anastasios, A.E. 2015. The Impact of PaperBased, Computer-Based and Mobile-Based Selfassessment on Students' Science Motivation and Achievement. Journal Computers in Human Behavior. (xxx):1-8.
Paramitha, L.A., Sumarjono, dan Parno. 2014. Pengaruh Model Pembelajaran Berbasis Masalah (PBM) Terhadap Keterampilan Berpikir Kreatif dan Metakognisi Pada Pembelajaran Fisika Peserta didik Kelas X SMA Negeri 2 Lumajang. Tesis tidak dipublikasi. FMIPA Universitas Negeri Malang.

Sahin, M. 2010. Effects of ProblemBased Learning on University Students' Epistemological Beliefs About Physics and Physics Learning and Conceptual Understanding of Newtonian Mechanics. Journal Science Education Technology. (19):266275.

Samuel, G., Sascha, W., Daniel, V., Frank, G., dan Joachim, F. 2013. Computer-Based Assessment of Complex Problem Solving: Concept, Implementation, and Application. Journal Education Technology Research and Development. 61:407-421.

Sulaiman, F. 2013. The Effectiveness of PBL Online on Physics Students' Creativity and Critical Thinking: A Case Study at Universiti Malaysia Sabah. International Journal of Education and Research. 1(3):116.

Trianto. 2010. Mendesain Model Pembelajaran Inovatif-Progresif. Jakarta: Kencana. 
Wahyudin, Sutikno, A., dan Isa. 2010.

Keefektifan Pembelajaran

Berbantuan Multimedia

Menggunakan Metode Inkuiri

Terbimbing untuk Meningkatkan

Minat dan Pemahaman Peserta

didik. Jurnal Pendidikan Fisika

Indonesia. (6):58-62.
Zabit, M.N.M. 2010. Problem-Based Learning on Students' Critical Thinking Skills in Teaching Business Education in Malaysia: A Literature Review. American Journal of Bussiness Education. 3(6):17-35. 